\title{
Durasi dan kualitas tidur hubungannya dengan obesitas pada anak sekolah dasar di Kota Yogyakarta dan Kabupaten Bantul
}

Dewi Marfuah', Hamam Hadi², Emy Huriyati ${ }^{3}$

\begin{abstract}
Background: The prevalence of obesity in Indonesia is expected to continue to increase each year. Many factors contribute to obesity, one of which is the duration and quality of sleep. Short sleep duration and poor sleep quality lead to increase energy intake and increase sedentary lifestyle that will have an impact on obesity in children.

Objective: To examine the difference in duration and quality of sleep between obese and non-obese children, and to examine whether short sleep duration and poor sleep quality were risk factors of obesity in elementary school children in City of Yogyakarta and Bantul Regency.

Methods: This was a case control study. A random sample of 244 obese and 244 grade-matched non-obese elementary school students were selected form a cross-sectional survey previously done in the City of Yogyakarta and Bantul Regency. Information of sleep quality was collected using sleep self report questionnaires, sleep duration using recall of physical activity during the last week, nutrient intakes using a food frequency questionnaires and socio-economic using structured questionnaires.

Results: There was a significant relationship between sleep duration and obesity. The odds of being obese was 1.7 $(O R=1,74,95 \% \mathrm{Cl}: 1.06-2.84)$ times higher in children who slept $<10$ hours/day and those children who slept $\geq 10$ hours/ day. Children with low quality of sleep was $1.9(\mathrm{OR}=1.88,95 \% \mathrm{Cl}: 0.95-3.71)$ times more likely to be obese than children with good quality of sleep. However, the association was not statistically significant.

Conclusion: Short sleep duration was associatied with increased odds of being obese in elementary school children.
\end{abstract}

KEYWORDS: sleep duration, sleep quality, obesity, elementary school children.

\begin{abstract}
ABSTRAK
Latar Belakang: Prevalensi obesitas di Indonesia diperkirakan akan terus meningkat setiap tahunnya. Banyak faktor yang berkontribusi terhadap obesitas, salah satunya adalah durasi dan kualitas tidur. Durasi tidur yang pendek dan kualitas tidur yang buruk menyebabkan peningkatan asupan energi dan peningkatan gaya hidup yang akan berdampak pada obesitas pada anak-anak.

Tujuan: Menguji perbedaan durasi dan kualitas tidur antara anak obesitas dan non obesitas, dan apakah durasi tidur yang pendek dan kualitas tidur yang buruk merupakan faktor risiko obesitas pada anak sekolah dasar di Yogyakarta.

Metode: Jenis penelitian ini adalah penelitian kasus kontrol. Sampel diambil secara acak sebanyak 244 anak SD obes dan 244 anak SD non-obes yang sebelumnya telah dipilih menggunakan metode cross-sectional yang dilakukan di Kota Yogyakarta dan Kabupaten Bantul. Data kualitas tidur diperoleh menggunakan kuesioner catatan tidur, sedangkan durasi tidur dengan recall aktivitas fisik selama satu minggu, asupan gizi dengan food frequency questionnaire, dan sosial ekonomi dengan kuesioner terstruktur.

Hasil: Terdapat hubungan yang signifikan antara durasi tidur dengan obesitas. Anak yang tidur <10 jam/hari kemungkinan mengalami obesitas 1.7 (OR=1,74, 95\% Cl: 1.06-2.84) kali lebih tinggi dibandingkan yang tidur >10 jam/hari. Anak dengan kualitas tidur yang buruk kemungkinan mengalami obesitas 1.9 (OR=1.88, 95\% Cl: 0.95-3.71) kali dibandingkan dengan yang kualitas tidurnya baik, namun secara statistik tidak signifikan.

Kesimpulan: Durasi tidur yang pendek berhubungan dengan peningkatan kemungkinan untuk mengalami obesitas pada anak sekolah dasar.
\end{abstract}

KATA KUNCI: durasi tidur, kualitas tidur, obesitas, anak SD

\footnotetext{
1 Pasca Sarjana Gizi dan Kesehatan Fakultas Kedokteran Universitas Gadjah Mada, Jl. Farmako, Sekip Utara Yogyakarta 55281, e-mail: dewi_marfuah@ ymail.com

2 Pasca Sarjana Gizi dan Kesehatan Fakultas Kedokteran Universitas Gadjah Mada, Jl. Farmako, Sekip Utara Yogyakarta 55281, e-mail: hamamhadi99@ gmail.com

3 Program Studi Gizi Kesehatan Fakultas Kedokteran Universitas Gadjah Mada, Jl. Farmako, Sekip Utara Yogyakarta 55281, e-mail:emyhuriyati@ ugm.ac.
} 


\section{PENDAHULUAN}

Obesitas merupakan masalah gizi yang sering dijumpai dan potensial untuk mengakibatkan gangguan kesehatan akibat berbagai komplikasi. Hal ini penting untuk diperhatikan mengingat obesitas mempunyai risiko komorbiditas yang tinggi, yang pada akhirnya akan dapat pula meningkatkan mortalitas (1). Prevalensi obesitas anak usia 6-11 tahun di Amerika Serikat meningkat dari $7 \%$ pada tahun 1980 menjadi $18 \%$ pada tahun 2010 , demikian pula prevalensi obesitas remaja usia $12-19$ tahun meningkat dari $5 \%$ pada tahun 1980 menjadi $18 \%$ pada tahun 2010. Pada tahun 2010, lebih dari sepertiga dari anak-anak dan remaja di Amerika Serikat mengalami kelebihan berat badan (2).

Prevalensi kegemukan (overweight dan obesitas) pada anak Indonesia juga mengalami kenaikan dari waktu ke waktu. Pada tahun 2007, prevalensi kegemukan pada anak Indonesia umur 6-14 tahun adalah 9,5\% untuk laki-laki dan $6,4 \%$ untuk perempuan dan angka ini naik menjadi 10,7\% untuk anak laki-laki dan $7,7 \%$ untuk anak perempuan pada tahun 2010. Riskesdas tahun 2007 menunjukkan bahwa di Provinsi Daerah Istimewa Yogyakarta, prevalensi berat badan lebih berdasarkan kategori IMT/U (indeks massa tubuh/umur) pada anak usia 6-14 tahun yaitu 7,6\% pada anak laki-laki dan $4,8 \%$ pada anak perempuan, sedangkan menurut data Riskesdas 2010, prevalensi berat badan lebih pada anak di Provinsi DIY adalah sebesar 7,8\% $(3,4)$.

Prevalensi obesitas di Indonesia diperkirakan akan terus meningkat terutama di daerah perkotaan berkaitan dengan adanya perubahan pola hidup dan kebiasaan makan masyarakat Indonesia (5). Tidur merupakan salah satu faktor risiko yang dilaporkan dapat meningkatkan kejadian obesitas. Penelitian di Australia menunjukkan bahwa prevalensi obesitas pada anak umur 5-12 tahun yang mempunyai waktu tidur $<10$ jam sebesar $22,3 \%$ (6). Durasi tidur yang pendek ( $<10$ jam) ditemukan berhubungan dengan meningkatnya risiko obesitas 2,61 kali lebih besar dibandingkan pada anak yang durasi tidurnya $\geq 10$ jam (6). Berdasarkan data dari National Sleep Foundation, kurangnya durasi tidur akan berdampak pada kurangnya aktivitas fisik yang diikuti dengan peningkatan pemasukan kalori yang merupakan salah satu faktor risiko kegemukan (7).

Sampai dengan saat ini, belum ada penelitian yang menjelaskan hubungan antara durasi dan kualitas tidur dengan kegemukan pada anak di Indonesia. Oleh karena itu peneliti merasa perlu untuk meneliti hubungan antara durasi dan kualitas tidur dengan obesitas pada anak sekolah dasar di Kota Yogyakarta dan Kabupaten Bantul.

\section{BAHAN DAN METODE}

Penelitian ini adalah penelitian observasional dengan rancangan kasus kontrol. Penelitian ini dilaksanakan di SD Kota Yogyakarta dan Kabupaten Bantul. Kasus dipilih secara random dari daftar anak obes yang ditemukan melalui survei yang dilakukan sebelumnya di Kota Yogyakarta dan Kabupaten Bantul. Sebanyak 224 kasus anak dengan IMT $\geq$ persentil ke 95 kurva WHO 2007 dipilih secara acak dari 580 anak obes yang berasal dari survei tersebut. Setiap kasus terpilih dicarikan pasangan kontrolnya yaitu teman sekelas yang tidak mengalami obes dan duduk paling dekat di sebelah kanan kasus tanpa melihat umur dan jenis kelaminnya.

Variabel terikat dalam penelitian ini adalah durasi dan kualitas tidur. Data kualitas tidur dikumpulkan melalui wawancara menggunakan kuesioner sleep self report. Kuesioner yang digunakan adalah kuesioner menurut penelitian sebelumnya yang telah divalidasi oleh peneliti $(8,9)$. Dari 26 pertanyaan, 23 pertanyaan setiap itemnya akan dinilai dengan skala likert 3 poin yaitu skor bernilai mulai dari 1 (jarang: jika perilaku tidur terjadi 0-1 kali/ minggu), 2 (kadang-kadang: jika perilaku tidur terjadi 2-4 kali/minggu), 3 (sering: jika perilaku tidur terjadi 5-7 kali/ minggu). Pertanyaan untuk nomer 4, 5, 6, 8, 11, dan 26 mempunyai skor berlawanan. Semakin tinggi skornya maka kualitas tidurnya semakin buruk $(8,9)$.

Tinggi badan anak sekolah diukur oleh peneliti dibantu enumerator menggunakan mikrotoise yang mempunyai ketelitian $0,1 \mathrm{~cm}$, sedangkan berat badan anak sekolah diukur oleh peneliti dibantu enumerator menggunakan timbangan injak digital yang mempunyai ketelitian $0,1 \mathrm{~kg}$. Data durasi tidur dikumpulkan menggunakan physical activity questionnaire for children yang dikombinasikan dengan formulir recall aktivitas fisik selama seminggu terakhir. Durasi tidur dihitung dari jam anak mulai tidur sampai jam anak bangun tidur, serta ditambah lamanya tidur siang. Data tentang asupan zat gizi dikumpulkan oleh peneliti dibantu enumerator menggunakan semi quantitative food frequency questionnaire (SQFFQ) dengan rentang waktu satu bulan terakhir. Data tentang sosial ekonomi dikumpulkan menggunakan kuesioner terstruktur.

Uji coba kuesioner dan recall aktivitas fisik dilakukan pada 30 siswa dari sekolah dasar di luar lokasi penelitian untuk menguji tingkat kesulitan pemahaman responden terhadap masing-masing kuesioner instrumen penelitian. Data penelitian dikumpulkan oleh para peneliti dibantu oleh tenaga enumerator mahasiswa gizi dan sarjana gizi yang sebelumnya telah dilatih menggunakan instrumen penelitian. IMT dihitung secara komputer dengan menggunakan software WHO Anthro 2007. Uji statistik dilakukan uji Chi Square, Mc Nemar, dan regresi logistik.

\section{HASIL}

\section{Karakteristik subjek penelitian}

Secara keseluruhan, karakteristik kasus hampir sama dengan kontrol, kecuali anak laki-laki $( \pm 13 \%)$ lebih 
besar pada kasus dibandingkan pada kontrol $(p<0,05)$ (Tabel 1).

Dalam analisis lebih lanjut, ditemukan anak laki-laki yang mempunyai durasi tidur lebih pendek dibandingkan anak perempuan. Rata-rata durasi tidur anak laki-laki 1,4 menit/hari lebih pendek dibandingkan anak perempuan. Anak laki-laki mempunyai skor kualitas tidur lebih buruk dibandingkan anak perempuan (Tabel 2).

\section{Durasi dan kualitas tidur}

Dalam penelitian ini ditemukan bahwa anak obes mempunyai durasi tidur lebih pendek dibandingkan anak yang tidak obes. Rata-rata durasi tidur anak obes 16,1 menit/hari lebih pendek dibandingkan anak tidak obes. Perbedaan tersebut dapat ditemukan baik di Kota Yogyakarta maupun di Kabupaten Bantul. Di samping itu, anak obes mempunyai kualitas tidur lebih buruk

Tabel 1. Karakteristik subjek penelitian antara kelompok kasus dan kontrol

\begin{tabular}{|c|c|c|c|c|c|c|c|c|}
\hline \multirow{3}{*}{ Karakteristik } & \multicolumn{4}{|c|}{ Status obesitas } & \multirow{2}{*}{\multicolumn{2}{|c|}{ Total }} & \multirow{3}{*}{$\chi^{2}$} & \multirow{3}{*}{$\mathbf{p}$} \\
\hline & \multicolumn{2}{|c|}{ Ya } & \multicolumn{2}{|c|}{ Tidak } & & & & \\
\hline & $n=244$ & $\%$ & $n=244$ & $\%$ & $n=488$ & $\%$ & & \\
\hline \multicolumn{9}{|l|}{ Kelompok usia } \\
\hline $6-8$ tahun & 84 & 34,4 & 83 & 34,0 & 167 & 34,2 & \multirow[t]{3}{*}{0,29} & \multirow[t]{3}{*}{0,863} \\
\hline 9-10 tahun & 114 & 46,7 & 119 & 48,8 & 233 & 47,8 & & \\
\hline 11-12 tahun & 46 & 18,9 & 42 & 17,2 & 88 & 18,0 & & \\
\hline \multicolumn{9}{|l|}{ Jenis kelamin } \\
\hline Laki-laki & 154 & 63,1 & 122 & 50,0 & 276 & 56,6 & \multirow[t]{2}{*}{8,54} & \multirow[t]{2}{*}{$0,003^{*}$} \\
\hline Perempuan & 90 & 36,9 & 122 & 50,0 & 212 & 43,4 & & \\
\hline \multicolumn{9}{|l|}{ Tempat tinggal } \\
\hline Kota besar & 13 & 5,3 & 19 & 7,8 & 32 & 6,6 & \multirow[t]{4}{*}{2,91} & \multirow[t]{4}{*}{0,405} \\
\hline Kota sedang & 34 & 13,9 & 43 & 17,6 & 77 & 15,8 & & \\
\hline Kota kecil & 174 & 71,3 & 163 & 66,8 & 337 & 69,1 & & \\
\hline Desa & 23 & 9,4 & 19 & 7,8 & 42 & 8,6 & & \\
\hline \multicolumn{9}{|l|}{ Pendidikan ibu } \\
\hline Tinggi & 200 & 82,0 & 191 & 78,3 & 391 & 80,1 & \multirow[t]{2}{*}{1,04} & \multirow[t]{2}{*}{0,307} \\
\hline Rendah & 44 & 18,0 & 53 & 21,7 & 97 & 19,9 & & \\
\hline \multicolumn{9}{|l|}{ Pekerjaan ibu } \\
\hline Tidak bekerja & 64 & 26,2 & 57 & 23,3 & 121 & 24,8 & \multirow[t]{2}{*}{0,53} & \multirow[t]{2}{*}{0,463} \\
\hline Bekerja & 180 & 73,8 & 187 & 76,7 & 367 & 75,2 & & \\
\hline \multicolumn{9}{|l|}{ Pendidikan ayah } \\
\hline Tinggi & 208 & 85,2 & 200 & 82,0 & 408 & 83,6 & \multirow[t]{2}{*}{0,95} & \multirow[t]{2}{*}{0,328} \\
\hline Rendah & 36 & 14,8 & 44 & 18,0 & 80 & 16,4 & & \\
\hline \multicolumn{9}{|l|}{ Pekerjaan ayah } \\
\hline Petani/nelayan & 2 & 0,8 & 3 & 1,2 & 5 & 1,0 & 7,16 & 0,306 \\
\hline Buruh/buruh tni & 21 & 8,7 & 36 & 14,9 & 57 & 11,8 & & \\
\hline Karyawan swasta & 70 & 29,0 & 71 & 29,3 & 141 & 29,1 & & \\
\hline PNS/TNI/Polri & 39 & 16,1 & 31 & 12,8 & 70 & 14,5 & & \\
\hline Wiraswasta & 93 & 38,4 & 80 & 33,1 & 173 & 35,8 & & \\
\hline Tidak bekerja & 1 & 0,4 & 3 & 1,2 & 4 & 0,8 & & \\
\hline Lainnya & 16 & 6,6 & 18 & 7,4 & 34 & 7,0 & & \\
\hline Pengeluaran keluarg & & & & & & & & \\
\hline sUMR & 20 & 8,2 & 22 & 91,0 & 446 & 91,4 & 0,10 & 0,747 \\
\hline >UMR & 224 & 91,8 & 222 & 9,0 & 42 & 8,6 & & \\
\hline Jumlah ART & & & & & & & & \\
\hline$>4$ orang & 96 & 39,3 & 99 & 40,6 & 195 & 60,0 & 0,07 & 0,782 \\
\hline$\leq 4$ orang & 148 & 60,7 & 145 & 59,43 & 293 & 40,0 & & \\
\hline
\end{tabular}

Sumber: data primer diolah, 2013

Tabel 2. Perbedaan rata-rata durasi tidur dan skor kualitas tidur pada siswa laki-laki dan perempuan

\begin{tabular}{|c|c|c|c|c|}
\hline Variabel & $\begin{array}{c}\text { Laki-laki }(n=276) \\
\text { mean } \pm S D\end{array}$ & $\begin{array}{c}\text { Perempuan }(n=212) \\
\text { mean } \pm S D\end{array}$ & $\begin{array}{l}\text { Mean diff. } \\
(95 \% \mathrm{Cl})\end{array}$ & p \\
\hline Durasi tidur (menit/hari) & $556,1 \pm 57,1$ & $557,5 \pm 60,1$ & $\begin{array}{c}-1,4 \\
(-11,8-9,1)\end{array}$ & 0,39 \\
\hline Skor kualitas tidur (jumlah skor/hari) & $38,2 \pm 5,6$ & $39,1 \pm 5,3$ & $\begin{array}{c}-0,9 \\
(-1,9-0,1) \\
\end{array}$ & $0,03^{*}$ \\
\hline
\end{tabular}

*Signifikan $(p<0,05)$ 
dibandingkan anak tidak obes, terutama pada anak-anak SD di Kota Yogyakarta yang memiliki kualitas tidur berbeda secara signifikan antara anak obes dan anak tidak obes $(p<0,05)$. Anak- anak SD di Kota Yogyakarta mempunyai rata-rata durasi tidur lebih pendek dibandingkan anakanak SD di Kabupaten Bantul (Tabel 3).

Anak obes mempunyai durasi tidur lebih pendek dibandingkan anak yang tidak obes baik weekday maupun weekend. Pada weekday, rata-rata durasi tidur anak obes 13,4 menit/hari lebih pendek dibandingkan anak tidak obes. Pada weekend, rata-rata durasi tidur anak obes 22,8 menit/hari lebih pendek dibandingkan anak tidak obes. Selain itu, anak SD pada weekday mempunyai durasi tidur lebih pendek dibandingkan weekend (Tabel 4).

\section{Durasi dan kualitas tidur dengan obesitas}

Berdasarkan National Sleep Foundation dan penelitian diAustralia, anak-anak seusia anak SD normalnya mempunyai lama tidur 10 jam/hari. Jika durasi tidur dalam penelitian ini dibedakan menjadi 2 kategori yaitu $\geq 10$ jam/ hari atau $<10$ jam/hari, maka diketahui bahwa $82,4 \%$ anak obes mempunyai durasi tidur <10 jam/hari, sedangkan pada anak yang tidak obes $72,9 \%$ (10\% lebih rendah) mempunyai durasi tidur $<10$ jam/hari. Anak obes mempunyai peluang tidur $<10$ jam/hari 1,73 (OR=1,73, 95\%Cl: 1,09-2,74) kali lebih besar dibandingkan yang tidak obes. Anak obes juga mempunyai peluang tidur dengan kualitas tidur yang buruk 2,23 (OR=2,23, $95 \% \mathrm{Cl}: 1,17-4,38)$ kali lebih besar dibandingkan anak yang tidak obes (Tabel 5).

Tabel 3. Perbedaan rata-rata durasi tidur dan skor kualitas tidur

\begin{tabular}{|c|c|c|c|c|}
\hline Variabel & $\begin{array}{l}\text { Obes }(n=244) \\
\text { mean } \pm S D\end{array}$ & $\begin{array}{c}\text { Tidak obes }(n=244) \\
\text { mean } \pm S D\end{array}$ & $\begin{array}{l}\text { Mean diff. } \\
(95 \% \mathrm{Cl})\end{array}$ & p \\
\hline \multicolumn{5}{|l|}{ Total } \\
\hline Durasi tidur (menit/hari) & $548,6 \pm 56,7$ & $564,7 \pm 59,0$ & $-16,1$ & 0,001 \\
\hline $\begin{array}{l}\text { Skor kualitas tidur } \\
\text { (jumlah skor/hari) }\end{array}$ & $39,0 \pm 5,8$ & $38,1 \pm 5,1$ & $\begin{array}{c}(-26,4-(-5,8)) \\
0,8 \\
(-0,1-1,9)\end{array}$ & $0,04^{*}$ \\
\hline \multicolumn{5}{|l|}{ Yogyakarta } \\
\hline $\begin{array}{l}\text { Durasi tidur } \\
\text { (menit/hari) }\end{array}$ & $544,8 \pm 54,0$ & $555,8 \pm 58,4$ & $\begin{array}{c}-11,1 \\
(-23,2-1,1)\end{array}$ & $0,03^{*}$ \\
\hline $\begin{array}{l}\text { Skor kualitas tidur } \\
\text { (jumlah skor/hari) }\end{array}$ & $39,2 \pm 5,8$ & $38,1 \pm 5,2$ & $\begin{array}{c}1,1 \\
(-0,1-2,3)\end{array}$ & $0,03^{*}$ \\
\hline \multicolumn{5}{|l|}{ Bantul } \\
\hline $\begin{array}{l}\text { Durasi tidur } \\
\text { (menit/hari) }\end{array}$ & $556,8 \pm 61,8$ & $583,7 \pm 56,1$ & $\begin{array}{c}-26,9 \\
(-45,5-(-8,2))\end{array}$ & $0,002^{*}$ \\
\hline $\begin{array}{l}\text { Skor kualitas tidur } \\
\text { (jumlah skor/hari) }\end{array}$ & $38,4 \pm 5,8$ & $38,1 \pm 4,7$ & $\begin{array}{c}0,3 \\
(-1,4-2,0)\end{array}$ & 0,36 \\
\hline
\end{tabular}

*Signifikan $(p<0,05)$

Tabel 4. Perbedaan rata-rata durasi tidur weekday dan weekend

\begin{tabular}{|c|c|c|c|c|}
\hline Variabel & $\begin{array}{c}\text { Obes }(n=244) \\
\text { mean } \pm S D\end{array}$ & $\begin{array}{c}\text { Tidak obes }(n=244) \\
\text { mean } \pm S D\end{array}$ & $\begin{array}{l}\text { Mean diff. } \\
(95 \% \mathrm{Cl})\end{array}$ & $\mathbf{p}^{*}$ \\
\hline \multicolumn{5}{|c|}{ Durasi tidur (menit/hari) } \\
\hline Weekday & $540,0 \pm 62,2$ & $553,5 \pm 61,5$ & $\begin{array}{c}-13,4 \\
-24,4(-)-2,4\end{array}$ & 0,008 \\
\hline Weekend & $570,1 \pm 65,1$ & $592,9 \pm 81,5$ & $\begin{array}{c}-22,8 \\
(-35,9-9,7)\end{array}$ & 0,000 \\
\hline
\end{tabular}

Tabel 5. Analisis Chi Square hubungan durasi dan kualitas tidur dengan kejadian obesitas

\begin{tabular}{|c|c|c|c|c|c|c|c|c|}
\hline \multirow{3}{*}{ Variabel } & \multicolumn{4}{|c|}{ Obesitas } & \multirow{3}{*}{$\chi^{2}$} & \multirow{3}{*}{$\mathbf{p}$} & \multirow{3}{*}{ OR } & \multirow{3}{*}{$95 \% \mathrm{Cl}$} \\
\hline & \multicolumn{2}{|c|}{ Ya } & \multicolumn{2}{|c|}{ Tidak } & & & & \\
\hline & $\mathbf{n}$ & $\%$ & $\mathbf{n}$ & $\%$ & & & & \\
\hline \multicolumn{9}{|l|}{ Durasi tidur } \\
\hline Pendek (< 10 jam/hari) & 201 & 82,4 & 178 & 72,9 & 6,24 & $0,012^{*}$ & 1,73 & $1,09-2,74$ \\
\hline Panjang ( $\geq 10$ jam/hari) & 43 & 17,6 & 66 & 27,1 & & & & \\
\hline Jumlah & 244 & 100,0 & 244 & 100,0 & & & & \\
\hline \multicolumn{9}{|l|}{ Kualitas tidur } \\
\hline Tidak baik (> 46 skor) & 35 & 14,3 & 12 & 7,0 & 6,97 & $0,008^{*}$ & 2,23 & $1,17-4,38$ \\
\hline Baik ( $\leq 46$ skor) & 209 & 86,7 & 227 & 93,0 & & & & \\
\hline Jumlah & 244 & 100,0 & 244 & 100,0 & & & & \\
\hline
\end{tabular}


Dalam analisis lebih lanjut ditemukan bahwa hubungan antara durasi tidur dengan kejadian kegemukan mengikuti pola dosis-respon (dose-response). Semakin pendek durasi tidur anak, maka risiko obesitas akan semakin meningkat. Anak yang tidur 9-10 jam/hari memiliki risiko obesitas 1,46 (OR=1,46, 95\% Cl: 0,91-2,34) kali lebih besar dibandingkan anak yang tidur $\geq 10$ jam/hari, sedangkan anak yang tidur $<9$ jam/hari memiliki risiko obesitas 2,12 (OR=2,12,95\%Cl:1,30-3,46) kali lebih besar dibandingkan anak yang tidur $\geq 10$ jam/hari (Gambar 1 ).

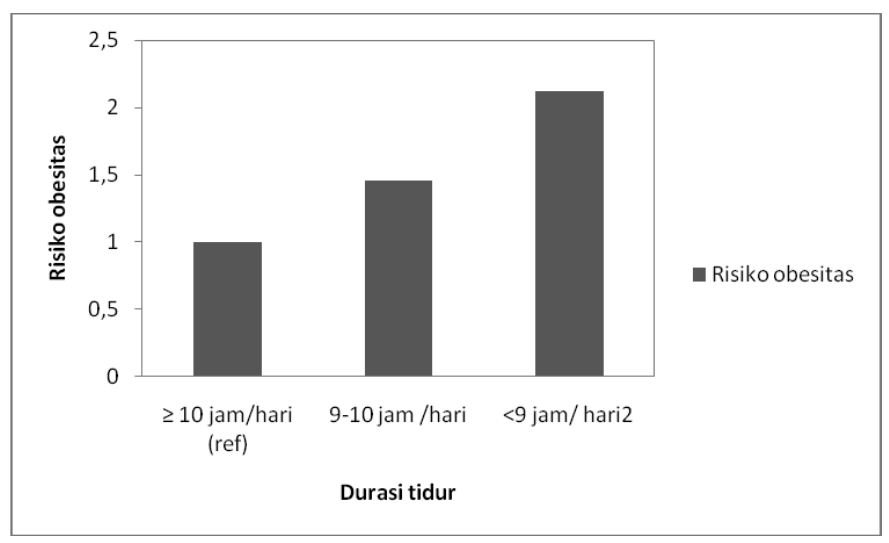

Gambar 1. Diagram dose response durasi tidur terhadap obesitas

Durasi dan kualitas tidur dengan obesitas yang melibatkan sedentary lifstyle, asupan energi, dan jenis kelamin

Pengaruh durasi tidur terhadap kejadian obesitas mungkin juga berkaitan dengan durasi sedentary lifestyle, maka dalam analisis lebih lanjut variabel sedentary lifestyle dimasukkan dalam model. Berdasarkan analisis multivariabel, maka model yang dipilih adalah model
5 sebagai model yang cukup baik untuk menjelaskan hubungan durasi tidur dengan kejadian obesitas. Pada model 5 sudah mempertimbangkan semua variabel signifikan terhadap kejadian obesitas, hasil $\mathrm{R}^{2}$ merupakan yang paling besar dan nilai deviance (-2 log Likelihood) yang paling kecil. Risiko kejadian obesitas pada anak SD dengan durasi tidur pendek 1,74 kali lebih besar dibandingkan anak yang durasi tidurnya panjang dengan mengontrol variabel sedentary lifestyle, asupan energi, dan jenis kelamin. Durasi tidur pendek dengan mengontrol variabel sedentary lifestyle, asupan energi, dan jenis kelamin dapat memprediksi kejadian obesitas pada anak SD di Kota Yogyakarta dan Kabupaten Bantul sebesar $17 \%$. Namun demikian, dalam analisis multivariat hubungan antara durasi tidur dengan kejadian obesitas menunjukkan bahwa secara independen durasi tidur dapat mempengaruhi obesitas tanpa pengaruh variabel lain (Tabel 6).

Pengaruh kualitas tidur terhadap kejadian obesitas mungkin juga berkaitan dengan durasi sedentary lifestyle, maka dalam analisis lebih lanjut variabel sedentary lifestyle dimasukkan dalam model. Berdasarkan analisis multivariabel, maka model yang dipilih adalah model 5 sebagai model yang cukup baik untuk menjelaskan hubungan kualitas tidur dengan kejadian obesitas. Pada model 5 sudah mempertimbangkan semua variabel signifikan terhadap kejadian obesitas, hasil $\mathrm{R}^{2}$ merupakan yang paling besar dan nilai deviance (-2 log Likelihood) yang paling kecil. Kualitas tidur dengan mengontrol variabel sedentary lifestyle, asupan energi, dan jenis kelamin dapat memprediksi kejadian obesitas pada anak SD di Kota Yogyakarta dan Kabupaten Bantul sebesar $17 \%$. Risiko kejadian obesitas pada anak dengan kualitas tidur yang tidak baik 1,88 kali lebih besar dibandingkan

Tabel 6. Analisis regresi logistik hubungan durasi tidur terhadap kejadian obesitas dengan melibatkan variabel sedentary lifestyle, asupan energi, jenis kelamin

\begin{tabular}{|c|c|c|c|c|c|}
\hline \multirow{3}{*}{ Variabel } & \multicolumn{5}{|c|}{ Kejadian obesitas } \\
\hline & Model 1 & Model 2 & Model 3 & Model 4 & Model 5 \\
\hline & OR $95 \% \mathrm{Cl}$ & OR 95\%Cl & OR $95 \% \mathrm{Cl}$ & OR 95\%Cl & OR 95\%Cl \\
\hline \multicolumn{6}{|l|}{ Durasi tidur } \\
\hline Pendek & $1,7^{*}$ & $1,7^{*}$ & $1,8^{*}$ & $1,7^{*}$ & $1,7^{*}$ \\
\hline Panjang & $(1,1-2,7)$ & $(1,1-2,7)$ & $(1,2-2,8)$ & $(1,1-2,7)$ & $(1,1-2,8)$ \\
\hline \multicolumn{6}{|l|}{ Sedentary lifestyle } \\
\hline Tinggi & & $6,9^{*}$ & & & $7,1^{*}$ \\
\hline Rendah & & $(4,6-10,3)$ & & & $(4,7-10,8)$ \\
\hline \multicolumn{6}{|l|}{ Asupan energi } \\
\hline Tinggi & & & $1,7^{*}$ & & $1,5^{*}$ \\
\hline Tidak tinggi & & & $(1,2-2,4)$ & & $(1,0-2,3)$ \\
\hline \multicolumn{6}{|l|}{ Jenis Kelamin } \\
\hline Laki-laki & & & & $0,6^{*}$ & $0,5^{*}$ \\
\hline Perempuan & & & & $(0,4-2,3)$ & $(0,3-0,8)$ \\
\hline $\mathrm{R}^{2}(\%)$ & 0,01 & 0,15 & 0,02 & 0,02 & 0,17 \\
\hline $\mathrm{n}$ & 488 & 488 & 488 & 488 & 488 \\
\hline $\begin{array}{l}\text { Deviance } \\
\text { (-2 log Likelihood) }\end{array}$ & 670,2 & 570,0 & 662,6 & 661,9 & 555,8 \\
\hline
\end{tabular}


dengan anak yang kualitas tidunya baik, namun secara statistik tidak signifikan (Tabel 7).

Pengaruh durasi dan kualitas tidur terhadap kejadian obesitas mungkin juga berkaitan dengan durasi sedentary lifestyle, maka dalam analisis lebih lanjut variabel sedentary lifestyle dimasukkan dalam model. Berdasarkan analisis multivariabel, maka model yang dipilih adalah model 7 sebagai model yang cukup baik untuk menjelaskan hubungan durasi dan kualitas tidur dengan kejadian obesitas. Pada model 7 sudah mempertimbangkan semua variabel signifikan terhadap kejadian obesitas, hasil $R^{2}$ merupakan yang paling besar dan nilai deviance (-2 log Likelihood) yang paling kecil. Durasi dan kualitas tidur dengan mengontrol variabel sedentary lifestyle, asupan energi, dan jenis kelamin dapat memprediksi kejadian obesitas pada anak SD di Kota Yogyakarta dan Kabupaten Bantul sebesar 18\% (Tabel 8).

Tabel 7. Analisis regresi logistik hubungan kualitas tidur terhadap kejadian obesitas dengan melibatkan variabel sedentary lifestyle, asupan energi, dan jenis kelamin.

\begin{tabular}{|c|c|c|c|c|c|}
\hline \multirow[b]{3}{*}{ Variabel } & \multirow[b]{2}{*}{ Model 1} & \multicolumn{4}{|c|}{ Kejadian obesitas } \\
\hline & & Model 2 & Model 3 & Model 4 & Model 5 \\
\hline & $\begin{array}{c}\text { OR } \\
95 \% \mathrm{Cl}\end{array}$ & $\begin{array}{c}\text { OR } \\
95 \% \mathrm{Cl}\end{array}$ & $\begin{array}{c}\text { OR } \\
95 \% \mathrm{Cl}\end{array}$ & $\begin{array}{c}\text { OR } \\
95 \% \mathrm{Cl}\end{array}$ & $\begin{array}{c}\text { OR } \\
95 \% \mathrm{Cl}\end{array}$ \\
\hline \multicolumn{6}{|l|}{ Kualitas tidur } \\
\hline Tidak baik & $2,2^{*}$ & 1,9 & $2,2^{*}$ & $2,3^{*}$ & 1,9 \\
\hline Baik & $(1,2-4,1)$ & $(0,97-3,7)$ & $(1,2-4,0)$ & $(1,2-4,2)$ & $(0,95-3,7)$ \\
\hline \multicolumn{6}{|l|}{ Sedentary lifestyle } \\
\hline Tinggi & & $6,8^{*}$ & & & $7,0^{*}$ \\
\hline Rendah & & $(4,5-10,1)$ & & & $(4,6-10,6)$ \\
\hline \multicolumn{6}{|l|}{ Asupan energi } \\
\hline Tinggi & & & $1,6^{*}$ & & 1,5 \\
\hline Tidak tinggi & & & $(1,1-2,3)$ & & $(0,96-2,2)$ \\
\hline \multicolumn{6}{|l|}{ Jenis kelamin } \\
\hline Laki-laki & & & & $0,6^{*}$ & $0,5^{*}$ \\
\hline Perempuan & & & & $(0,4-0,8)$ & $(0,3-0,8)$ \\
\hline $\mathrm{R}^{2}(\%)$ & 0,01 & 0,15 & 0,02 & 0,02 & 0,17 \\
\hline $\mathrm{n}$ & 488 & 488 & 488 & 488 & 488 \\
\hline $\begin{array}{l}\text { Deviance } \\
\text { (-2 log Likelihood) }\end{array}$ & 669,4 & 571,3 & 663,0 & 660,6 & 557,4 \\
\hline
\end{tabular}

Tabel 8. Analisis regresi logistik hubungan durasi dan kualitas tidur terhadap kejadian obesitas dengan melibatkan variabel sedentary lifestyle, asupan energi, dan jenis kelamin

\begin{tabular}{|c|c|c|c|c|c|c|c|}
\hline \multirow{3}{*}{ Variabel } & \multicolumn{7}{|c|}{ Kejadian Obesitas } \\
\hline & Model 1 & Model 2 & Model 3 & Model 4 & Model 5 & Model 6 & Model 7 \\
\hline & OR $95 \% \mathrm{Cl}$ & OR $95 \% \mathrm{Cl}$ & OR $95 \% \mathrm{Cl}$ & OR $95 \% \mathrm{Cl}$ & OR $95 \% \mathrm{Cl}$ & OR $95 \% \mathrm{Cl}$ & OR $95 \% \mathrm{Cl}$ \\
\hline \multicolumn{8}{|l|}{ Durasi tidur } \\
\hline Pendek & $1,7^{*}$ & & $1,8^{*}$ & $1,7^{*}$ & $1,8^{*}$ & $1,7^{*}$ & $1,8^{*}$ \\
\hline Panjang & $(1,1-2,7)$ & & $(1,1-2,7)$ & $(1,1-2,8)$ & $(1,2-2,8)$ & $(1,1-2,7)$ & $(1,1-2,9)$ \\
\hline \multicolumn{8}{|l|}{ Kualitas tidur } \\
\hline Tidak baik & & $2,2^{*}$ & $2,3^{*}$ & 1,9 & $2,2^{*}$ & $2,3^{*}$ & 1,9 \\
\hline Baik & & $(1,2-4,1)$ & $(1,2-4,2)$ & $(0,9-3,8)$ & $(1,2-4,1)$ & $(1,2-4,2)$ & $(0,9-3,7)$ \\
\hline \multicolumn{8}{|l|}{ Sedentary lifestyle } \\
\hline Tinggi & & & & $6,8^{*}$ & & & $6,9^{*}$ \\
\hline Rendah & & & & $(4,5-10,1)$ & & & $(4,6-10,5)$ \\
\hline \multicolumn{8}{|l|}{ Asupan energi } \\
\hline Tinggi & & & & & $1,6^{*}$ & & 1,5 \\
\hline Tidak tinggi & & & & & $(1,1-2,6)$ & & $(0,9-2,2)$ \\
\hline \multicolumn{8}{|l|}{ Jenis Kelamin } \\
\hline Laki-laki & & & & & & $0,6^{*}$ & $0,5^{*}$ \\
\hline Perempuan & & & & & & $(0,4-0,8)$ & $(0,3-0,8)$ \\
\hline $\mathrm{R}^{2}(\%)$ & 0,01 & 0,01 & 0,02 & 0,16 & 0,03 & 0,03 & 0,18 \\
\hline $\mathrm{n}$ & 488 & 488 & 488 & 488 & 488 & 488 & 488 \\
\hline $\begin{array}{l}\text { Deviance } \\
\text { (-2 log likelihood) }\end{array}$ & 671,1 & 669,4 & 662,8 & 566,2 & 655,8 & 654,4 & 552,3 \\
\hline
\end{tabular}




\section{BAHASAN}

\section{Karakteristik subjek penelitian}

Berdasarkan hasil analisis variabel karakteristik, yang berbeda secara signifikan antara siswa obes dan tidak obes adalah variabel jenis kelamin. Anak laki-laki lebih banyak yang obesitas dibandingkan dengan anak perempuan. Hal ini sejalan dengan penelitian pada anak umur 5-12 tahun di Australia yang menunjukkan bahwa pada kelompok obes lebih banyak yang berjenis kelamin laki-laki sebesar $8,9 \%$ dibandingkan anak perempuan yaitu $6,6 \%(6)$. Hasil penelitian ini menunjukkan bahwa anak laki-laki mempunyai durasi tidur lebih pendek dibandingkan anak perempuan. Durasi tidur pendek berisiko menyebabkan obesitas.

Penelitian lain menunjukkan bahwa anak laki-laki memiliki lebih banyak waktu luang dibandingkan anak perempuan yang disebabkan anak laki-laki mempunyai aktivitas rumah yang lebih sedikit. Waktu luang yang dimiliki anak laki-laki digunakan untuk melakukan aktivitas screen based seperti: main game, playstation, dan komputer. Hal ini menjadi salah satu faktor yang menyebabkan kejadian obesitas pada anak laki-laki lebih tinggi dibandingkan anak perempuan (10).

\section{Hubungan durasi tidur dengan kejadian obesitas}

Anak SD yang mempunyai durasi tidur pendek berisiko 1,73 kali lebih besar mengalami obesitas dibandingkan dengan anak yang durasi tidurnya panjang. Hasil ini sesuai dengan penelitian di Australia yang menunjukkan bahwa durasi tidur pendek ( $<10$ jam) dapat meningkatkan risiko obesitas pada anak usia 5-12 tahun dengan OR sebesar 2,61 dibandingkan anak yang durasi tidurnya panjang yaitu $\geq 10$ jam (5). Patel dan Hu menyebutkan bahwa pada anak-anak yang mempunyai durasi tidur pendek berhubungan dengan kejadian obesitas, sedangkan pada beberapa penelitian menyebutkan bahwa durasi tidur panjang tidak berhubungan dengan kejadian obesitas pada anak(11).

Hubungan durasi tidur terhadap kejadian obesitas dengan mengontrol variabel sedentary lifestyle, asupan energi, dan jenis kelamin dapat memprediksi kejadian obesitas pada anak SD di Kota Yogyakarta dan Kabupaten Bantul yang meningkat menjadi $17 \%$. Risiko kejadian obesitas pada anak dengan durasi tidur pendek 1,74 kali lebih besar dibandingkan dengan anak yang durasi tidurnya panjang setelah dikontrol variabel sedentary lifestyle, asupan energi, dan jenis kelamin. Penelitian kohort menjelaskan bahwa anak yang mempunyai durasi tidur pendek dapat menyebabkan sedentary lifestyle yang tinggi dan peningkatan asupan energi, sehingga mengakibatkan obesitas pada anak (11).

Durasi tidur yang pendek dapat meningkatan rasa lapar, meningkatkan kesempatan untuk makan, terjadi perubahan termoregulasi, dan meningkatkan kelelahan. Peningkatan rasa lapar dan peningkatan kesempatan untuk makan akan meningkatan asupan energi, sedangkan terjadinya perubahan termoregulasi dan peningkatan kelelahan akan menurunkan energy expenditure. Peningkatan asupan energi yang tidak diimbangi dengan energy expenditure dapat menyebabkan obesitas (11).

Salah satu mekanisme durasi tidur pendek yang dapat mempengaruhi kenaikan berat badan adalah dengan meningkatnya asupan energi. Berdasarkan penelitian pada hewan menunjukkan bahwa durasi tidur pendek dapat menyebabkan hyperphagia (peningkatan rasa lapar) yang pada manusia juga menunjukkan efek yang sama. Penelitian ini membandingkan 4 jam dengan 10 jam tidur untuk setiap malam selama 2 hari yang hasilnya menunjukkan bahwa subjek yang tidurnya 4 jam setiap malam mempunyai rasa lapar dan nafsu makan yang lebih tinggi daripada yang tidurnya 10 jam dalam semalam. Peningkatan asupan makan tersebut terutama makanan tinggi lemak dan tinggi karbohidrat. Perubahan ini berhubungan dengan peningkatan ghrelin dalam serum dan penurunan leptin dalam serum. Hal ini membuktikan bahwa kurang tidur dapat mempengaruhi regulator perifer rasa lapar (11).

Tidur yang kurang (2-4 jam sehari) dapat mengakibatkan kehilangan $18 \%$ leptin dan meningkatkan $28 \%$ ghrelin yang dapat menyebabkan bertambahnya nafsu makan kira-kira sebesar 23-24\%. Leptin adalah protein hormon yang diproduksi jaringan lemak yang berfungsi mengendalikan cadangan lemak dan mempengaruhi nafsu makan, sedangkan ghrelin adalah hormon yang dapat mempengaruhi rasa lapar dan kenyang. Apabila leptin menurun dan ghrelin meningkat dapat meningkatkan rasa lapar dan membuat metabolisme melambat serta berkurangnya kemampuan membakar lemak dalam tubuh (12).

Dalam review beberapa penelitian menunjukkan hasil bahwa intervensi pengurangan durasi tidur dapat menyebabkan peningkatan asupan energi yang konsisten. Kemudian dapat disimpulkan dari beberapa penelitian bahwa secara keseluruhan, pengurangan tidur dapat meningkatkan asupan yang berlebih sebesar $>250 \mathrm{kkal} /$ hari. Hasil review ini juga dijelaskan dampak pengurangan tidur dan keluaran energi menunjukkan hasil yang bervariasi. Hal tersebut dimungkinkan karena pengurangan tidur secara berulang tidak mempengaruhi keluaran energi karena tidak menemukan beda keluaran energi pada tidur pendek dengan tidur panjang. Dengan demikian dapat diketahui bahwa dampak pengurangan tidur terhadap keluaran energi lebih kecil daripada pengaruh pada kondisi hormonal yang menyebabkan peningkatan asupan energi. Peningkatan jumlah asupan energi tersebut cukup besar untuk menimbulkan keseimbangan energi positif yang berdampak pada peningkatan simpanan energi sehingga menimbulkan obesitas (13). 
Beberapa pendapat dikemukakan bahwa dalam lingkungan yang sudah tersedia makanan, durasi tidur yang pendek dapat memberikan peluang peningkatan untuk makan, terutama jika sebagian besar waktu luang hanya dihabiskan dalam kegiatan tidak aktif (sedentary lifestyle) seperti menonton televisi yang biasanya diikuti dengan ngemil atau makan snack. Kurang tidur yang lama juga jelas mengarah pada perasaan kelelahan. Kelelahan ini dapat menyebabkan penurunan aktivitas fisik. Bahkan, penelitian pada anak-anak telah menemukan durasi tidur pendek berhubungan dengan peningkatan menonton televisi dan berkurangnya partisipasi dalam olahraga yang terorganisir (11). Terdapat dua mekanisme utama pada kegiatan menonton televisi yang menjadi penyumbang terjadinya obesitas, di antaranya adalah terjadinya penurunan energy expenditure akibat kurangnya aktivitas fisik sedang dan berat. Kedua adalah selama menonton televisi anak-anak akan terpapar iklan-iklan makanan yang tidak sehat (junk food) yang akan mempengaruhi pemilihan makanan (14).

Dalam penelitian ini menunjukkan anak laki-laki mempunyai durasi tidur yang lebih pendek dibandingkan anak perempuan. Hal ini sejalan dengan penelitian di Australia yang menunjukkan anak laki-laki lebih banyak menghabiskan waktunya untuk melakukan aktivitas sedentari seperti menonton televisi dan internet, main game, atau playstation. Hal ini yang dapat menyebabkan anak laki-laki mempunyai durasi tidur lebih pendek dibandingkan anak perempuan (15).

Dalam analisis multivariat, hubungan antara durasi tidur dengan kejadian obesitas menunjukkan bahwa secara independen durasi tidur dapat mempengaruhi obesitas tanpa pengaruh variabel lain. Dalam model ini menunjukkan bahwa sedentary lifestyle, asupan energi, dan jenis kelamin secara independen dapat memengaruhi obesitas.

Penelitian ini menunjukkan bahwa anak sekolah dasar di Kota Yogyakarta dan Kabupaten Bantul mempunyai rata-rata durasi tidur lebih pendek dari anjuran National Sleep Foundation, padahal tidak semua anak sekolah dasar yang dijadikan sampel penelitian mengalami obesitas. Hal ini bisa disebabkan oleh faktor lain misalnya adanya ketersediaan makanan di rumah serta kurangnya aktivitas fisik yang sedang dan berat. Durasi tidur pendek tidak selalu diikuti dengan asupan energi yang tinggi, karena ketersediaan pangan setiap rumah berbeda-beda. Meskipun kesempatan untuk makan tersedia dan nafsu makan meningkat, jika tidak ada ketersediaan pangan di rumah, maka anak tidak akan mempunyai asupan energi yang tinggi. Durasi tidur pendek dapat menyebabkan obesitas karena kurangnya aktivitas fisik yang sedang dan berat serta adanya peningkatan perilaku sedentari seperti menonton televisi dan bermain komputer, laptop, atau tablet.

\section{Hubungan kualitas tidur dengan kejadian obesitas}

Anak SD yang mempunyai kualitas tidur tidak baik mempunyai risiko 2,23 kali lebih besar mengalami obesitas dibandingkan dengan anak yang kualitas tidurnya baik. Hasil penelitian ini sejalan dengan penelitian Owens et al yang menunjukkan bahwa anak yang mempunyai kualitas tidur tidak baik yang dijelaskan dengan nilai skor semakin tinggi akan lebih berisiko menyebabkan obesitas (9).

Hubungan kualitas tidur terhadap kejadian obesitas dengan mengontrol variabel sedentary lifestyle, asupan energi, dan jenis kelamin dapat memprediksi kejadian obesitas pada anak SD di Kota Yogyakarta dan Kabupaten Bantul sebesar $17 \%$. Risiko kejadian obesitas pada anak dengan kualitas tidur yang tidak baik 1,88 kali lebih besar dibandingkan dengan anak dengan kualitas tidur yang baik, namun secara statistik tidak signifikan.

Penelitian di Arab menunjukkan bahwa kualitas tidur yang buruk berhubungan dengan obesitas pada anak dan remaja. Anak yang mempunyai kualitas buruk lebih berisiko mengakibatkan obesitas daripada anak yang mempunyai kualitas tidur baik. Anak yang mempunyai kualitas tidur yang buruk akan mengakibatkan perasaan kelelahan pada saat bangun tidur. Kelelahan ini dapat menyebabkan penurunan aktivitas fisik dan terjadi peningkatan menonton televisi serta berkurangnya partisipasi dalam olah raga yang terorganisir $(11,16)$. Menonton televisi dapat meningkatkan asupan energi, terutama ngemil makanan tinggi energi pada saat menonton televisi (17). Hasil review menunjukkan bahwa sedentary lifestyle berupa menonton TV dan screen based yang tinggi memiliki hubungan terbalik dengan asupan buah dan sayur serta memiliki hubungan positif dengan asupan snack, konsumsi fast-food, dan makanan yang digoreng dengan densitas energi tinggi sehingga berkontribusi terhadap terjadinya obesitas (18).

Penelitian ini menunjukkan bahwa anak yang mempunyai kualitas tidur yang buruk dapat menyebabkan perilaku sedentari yang tinggi, seperti menonton televisi, bermain komputer, laptop, atau tablet.

\section{KESIMPULAN DAN SARAN}

Dari hasil penelitian, maka dapat diambil kesimpulan bahwa anak obes mempunyai durasi tidur lebih pendek dibandingkan anak tidak obes. Semakin pendek durasi tidur anak, semakin tinggi risiko obesitas pada anak. Anak laki-laki mempunyai durasi tidur lebih pendek dibandingkan anak perempuan. Anak obes mempunyai kualitas tidur lebih buruk dibandingkan dengan anak tidak obes. Setelah dikontrol variabel sedentary lifestyle, asupan energi, dan jenis kelamin, anak yang mempunyai durasi tidur pendek berisiko obesitas 1,74 kali lebih tinggi dibandingkan anak yang mempunyai durasi tidur panjang. Hal ini berbeda 
dengan hubungan kualitas tidur terhadap kejadian obesitas menunjukkan hubungan yang tidak signifikan.

Berdasarkan kesimpulan tersebut, maka disarankan bagi orang tua sebaiknya mulai memperhatikan waktu tidur anak agar tidak kurang dari 10 jam/hari serta memperhatikan pola tidur anak sebagai salah satu upaya pencegahan obesitas sejak dini serta orang tua juga perlu memperhatikan ketersediaan makanan di rumah yang tidak tinggi energi serta mengatur perilaku sedentari anak seperti menonton televisi, bermain komputer, laptop, atau tablet. Bagi peneliti lain yang ingin melakukan penelitian serupa hendaknya melakukan pengukuran variabel melalui jalur metabolik dengan melihat hormon ghrelin dan leptin serta insulin sensitifity.

\section{RUJUKAN}

1. Faizah Z. Faktor risiko obesitas pada murid sekolah dasar usia 6-7 tahun di Semarang. [Tesis]. Semarang: Progam Pendidikan Dokter Spesialis 1 Fakultas Kedokteran Universitas Diponegoro; 2004.

2. Centers for Disease Control and Prevention. Childhood obesity facts._Atlanta, GA: U.S. Department of Health and Human Services; 2013.

3. Departemen Kesehatan RI. Riset kesehatan dasar 2007. Jakarta: Departemen Kesehatan RI; 2008.

4. Departemen Kesehatan RI. Riset kesehatan dasar 2007. Jakarta: Departemen Kesehatan RI; 2010.

5. Hadi H. Handout seminar nasional obesitas. Yogyakarta: Universitas Gajah Mada; 2004.

6. Shi Z, Taylor AW, Gill TK, Tuckerman J, Adams R, Martin J. Short sleep duration and obesity among Australian children. BMC Public Health 2010.

7. National Sleep Foundation. Sleep in america poll. National sleep foundation, woshington. Available from: URL : http:/www. sleepfoundation. org/site/.hulXKj MOIxF/b.2417355/k.143E/2002 Sleep in America Poll. htm. Accessed 2002.
8. Litsenburg RRL, Waumans RC, Berg GVD, Gemke RJBJ. Sleep habits and sleep disturbances in dutch children: a population-based study. Eur J Pediatr 2010.

9. Owens JA, Maxim R, Nabile C, McGuinn M, Msall M. Parental and self-report of sleep in children with attention- deficit/hyperactive disorder. Arch Pediatr Med 2000;154:549-55.

10. Carvalho MJ. Gender and children's time use. Available from: http://www.lume.ufrgs.br/bitstream/ handle/10183/538/000339102.pdf=sequence 1 . Accessed 2001.

11. Patel SR, Hu FR. Short sleep duration and weight gain: a systematic review. Obesity Journal 2008;16:643-53.

12. Patel SR, Malhotra A, White DP, Gottlieb DJ, Hu FB. A prospective study of sleep duration and mortality risk in women. Pubmed 2004;27:440-4.

13. Morselli LL, Guyon A, Spiegel K, et al. Sleep and metabolic function. European Journal of Physiology 2012;463(1):139-60.

14. Huriyati E. Aktivitas fisik pada remaja SLTP Kota Yogyakarta dan Kabupaten Bantul serta hubungannya dengan kejadian obesitas. [Tesis]. Yogyakarta: Universitas Gadjah Mada; 2007.

15. Biggs SN, Lushington K, Martin JA, Heuvel VC, Kennedy D. Gender, socioeconomic, and ethnic differences in sleep patterns in school-aged children. Sleep Medicine; 2013.

16. Bawazeer NM, Al-daghri NM, Valsamakis G, et al. Sleep duration and quality associated with obesity among Arab children. Obes 2009;17(12):2251-3.

17. Sjarif DR. Childhood obesity: evaluation and management. Naskah Lengkap National Obesity Symposium II 2003. Surabaya; 2003:123-39.

18. Pearson N, Biddle SJH. Sedentary behavior and dietary intake in children, adolescents, and adults. A systematic review. Am J Preventive Med 2011;41(2):178-88. 